\title{
Jana Lengová: Stephanie Wurmbrand-Stuppachová. Život, dielo, korešpondencia
}

\author{
Bratislava : Ústav hudobnej vedy SAV, 2019, 248 s. ISBN 978-80-89135-41-7
}

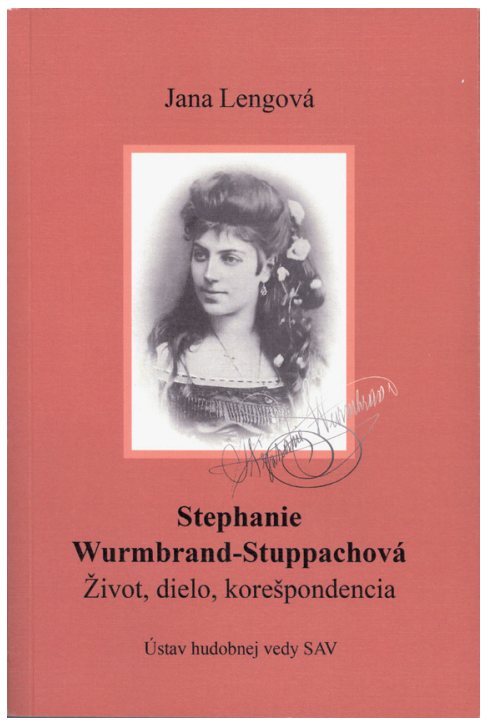

Monografia venovaná pozoruhodnej osobnosti skladatel'ky a klavírnej virtuózky, bratislavskej rodáčky, od hudobnej historičky Jany Lengovej je určite viac, než bežnou muzikologicky spracovanou personálnou biografiou. Autorka sa úspešne pokúša vtiahnut čitatela do atmosféry doby, spoločenských konvencií šlachtických a meštianskych kruhov na pozadí hudobnej kultúry stredoeurópskeho provinčného centra, akým bola $\mathrm{v}$ druhej polovici 19. storočia Bratislava. Kniha je okrem bohatej faktografie popretkávaná životnými osudmi nielen samotnej Stephanie a jej príbuzných, osobitne sestry Seraphine, ale aj mnohých dalších osobností, vrátane sledovania ich vzájomných kontaktov, v niektorých prípadoch aj $\mathrm{v}$ hypotetickej, pritom vedecky korektnej rovine. Aristokratické prostredie, v ktorom sa Stephanie Wurmbrand-Stuppachová, rod. Vrabélyová celý život pohybovala, si v jej dobe ešte starostlivo uchovávalo prvky noblesy a spoločenskej prestíže. Na sklonku „belle epoque“, za súmraku monarchie, ked” sa životný príbeh Stephanie chýlil ku koncu, však tento svet smeroval $\mathrm{k}$ nevyhnutnému úpadku, čo zahaluje príbeh našej hrdinky do pavučiny nostalgie a krásnych spomienok, zviditel'nený $\mathrm{v}$ jej korešpondencii i literárnych dielach z posledných desatročí života.

Úvodné dve kapitoly knihy Jany Lengovej venované biografii Stephanie na pozadí spomínaných súvislostí sú plné odkazov a citácií $\mathrm{z}$ dobových prameňov, vrátane detailných informácií z koncertného života Bratislavy v mladých rokoch skladatelky. Tento úctyhodný pramenný materiál (archívne dokumenty, články $\mathrm{z}$ dobovej tlače, korešpondencia a iná sekundárna literatúra) dodáva dôveryhodnost' Lengovej úvahám o vztahoch ambicióznej umelkyne k umeleckým osobnostiam, rodinným príslušníkom i manželovi, ktoré dokumentujú aj dedikácie niektorých jej diel. Čitatel' sa podrobne oboznámi s prvými úspechmi dvoch nadaných sestier - brilantných klaviristiek -, s ich koncertnými vystúpeniami a dobovými ohlasmi. Zdá sa, že hudobným talentom Stephanie predčila svoju o devät rokov staršiu sestru Seraphine, ktorá nastúpila kariéru koncertnej umelkyne. Stephanie mala všetky predpoklady, aby ju v tom mohla nasledovat', jej životné osudy sa však vyvíjali inak a po sobáši s rakúskym šlachticom Ernstom Wurmbrandom svoj hudobný talent aspoň sčasti pretavila do skladatelskej tvorby. Autorka publikácie venuje značnú pozornost' aj kontaktom Stephanie s osobnostami kultúrneho a hudobného života. Osobitný priestor má $\mathrm{v}$ jej publikácii priatelstvo $\mathrm{s}$ bratislavským archivárom Jánom Batkom na základe zachovanej korešpondencie (obsah 51 listov v nemeckom origináli z Archívu mesta Bratislavy autorka zverejňuje aj s po- 
známkovým aparátom v záverečnej kapitole knihy) a tiež príbeh jej nenaplneného platonického vztahu s Johannesom Brahmsom. Jana Lengová neodolala pokušeniu rozvinút širšie túto naoko senzačnú či „bulvárnu“ tému, rieši ju však so sebe vlastnou taktnostou a objektivizujúcim nadhladom, opierajúc sa o seriózne zdroje a svedectvá. Je zaujímavé sledovat', ako eliminuje všetky náznaky bulvárnosti, ktorými by bolo možné obotkat tento príbeh dvoch spriaznených umeleckých duší, a to aj napriek tomu, že tieto náznaky explicitne spomína, čo je, samozrejme, čitatel'sky prítažlivé a vo faktograficky hutnej vedeckej publikácii nepochybne osviežujúce. Nie je to však jediný prípad, ked' Lengová dbá na ludský a psychologizujúci obraz postáv svojej knihy. Zdá sa, že práve tento prístup - empatický zmysel pre detaily a maličkosti každodenného života - odlišuje charakter jej knihy od bežných vedecky spracovaných monografií hudobníkov. Tajomstvo Lengovej úspechu tkvie v tom, že to robí bez toho, aby publikáciu príliš „beletrizovala“.

Obsahom tretej kapitoly knihy je muzikologická analýza tvorby Stephanie Wurmbrand-Stuppachovej, obsahujúcej diela pre klavír, piesne a niektoré dalšie komorné skladby. V dobovom kontexte boli tieto diela určené pre hudobné salóny, ako však Lengová zdôrazňuje, pojem „salónna hudba“ nemal ešte v 2. polovici 19. storočia negatívny význam, ale zahŕňal aj kvalitatívne hodnotnú hudobnú tvorbu (v tom čase napríklad za skladatela salónnej hudby považovali aj Chopina). Klavírnu tvorbu Wurmbrand-Stuppachovej Lengová štruktúrovala na charakteristické skladby, štylizácie tancov (najmä valč́ky), fantázie (fantastické skladby), etudy (klavírne štúdie), skladby pre dva klavíry a klavír štvorručne. Osobitnú pozornost̉ venovala skladatel'kinmu najznámejšiemu opusu, klavírnemu cyklu Die schöne Melusine op. 33 (v podtitule označenému ako hudobné ilustrácie). Skladatel'ku inšpiroval rovnomenný cyklus akvarelov Moritza von Schwinda a vytvorila jeho pozoruhodný hudobný pendant plný zvukomalby, farebnosti a melodickej invencie. Dielo bolo publikované vo viacerých vydaniach, najstaršie z nich obsahuje kratšiu verziu cyklu s 10 častami, v neskorších vydaniach je cyklus skompletizovaný na 11 častí. Tri časti cyklu neskôr zinštrumentoval pre orchester viedenský vydavatel' a skladatel Bohumil Pazdírek. Vo svojej analýze klavírneho diela skladatel'ky okrem sémantických aspektov J. Lengová vyzdvihla invenčné stvárnenie melódie, zmysel pre delikátnu zvukovost' a zvukomalbu, ktorá v niektorých kompozíciach podla jej názoru dosiahla predimpresionistickú zvukovost' pri zachovávaní rozšírenej chromatizovanej tonálnej harmónie. $\mathrm{Na}$ druhej strane eviduje tendencie $\mathrm{k}$ sentimentalite vo valčíkových štylizáciách či určitý schematizmus v reprízových trojdielnych formových štruktúrach charakteristických skladieb. V záverečných pasážach kapitoly J. Lengová analyzuje skladatelkinu komornú tvorbu - skladby pre husle a klavír (celkovo pät diel, z nich sa zachovali štyri) a vokálne diela (piesne, vokálne kvinteto), ako aj literárnu tvorbu skladatel'ky (knižne vyšli štyri diela - zbierka aforizmov a úvah Betrachtungen, literárne črty a poviedky Gesammeltes, a memoárové knižočky Erinnerungsmomente, Erlebtes). Posledná, štvrtá kapitola knihy sa venuje zachovanej korešpondencii Stephanie Wurmbrand-Stuppachovej, kde autorka sumarizuje doterajšie poznatky a pridáva už spomínaný kompletný prepis korešpondencie skladatelky adresovanej Johannovi Batkovi, doplnený o poznámkový aparát, ktorý je pre poznanie skladatelkinej osobnosti a jej postojov velmi prínosný.

V prílohe knihy Jana Lengová uvádza zoznam diel skladatelky, vrátane niektorých rukopisných verzií. V zozname nezachovaných diel chýba skladba Nachtmusik auf Kieferstädtel op. 64, o ktorej sa autorka zmieňuje v prvej kapitole. Tvorbe Stephanie Wurmbrand-Stuppachovej venovala v uplynulých rokoch pozornost' aj nemecká klavírna pedagogička Isolde Weiermüller-Backes, ktorá je autorkou publikácie Klaviermusik von Komponistinnen vom 17. bis zum 21. Jahrhundert (Düsseldorf : Staccato Verlag, 2003). Vo svojej databáze skladatelkiných diel, ktorá je prístupná aj na internetovej stránke www.klassika.info, eviduje ešte niektoré dalšie vydania diel Stephanie Wurmbrand-Stuppachovej: Vier Klavierstücke (Liebeslied, Orientalischer Marsch, 
Menuetto, Trauerkläge), Wien : Wetzler, b.r. - zrejme ide o staršiu verziu rozšírenej zostavy piatich klavírnych skladieb, ktorú Lengová eviduje ako op. 25 -, Zehn Klavierstücke (Begegnung, Frage, Vergebliches Ständchen, Sezam, Minnelied, Willis Nachtreigen, Liebeslied, Orientalischer Marsch, Menuetto, Trauerkläge), bližšie neznámu tlač zostavenú zo skladieb z rôznych vydaní. Lengová sama konštatuje vo svojom úvodnom texte $\mathrm{k}$ zoznamu diel, že najmä charakteristické skladby skladatelky vychádzali vo viacerých vydaniach a niekedy $\mathrm{v}$ rôznorodých zostavách. Je zjavné, že tento problém bude potrebné v budúcnosti pri zostavovaní kompletného zoznamu diel Wurmbrand-Stuppachovej vyriešit, azda najskôr diferencovaním medzi cyklicky koncipovanými dielami a volnými sledmi charakteristických skladieb, ktoré možno vnímat aj ako samostatné kompozície. Táto úloha, samozrejme, nie je jednoduchá. Weiermüller-Backes vo svojom zozname, ktorý tiež nie je kompletný a dal by sa doplnit na základe databázy Lengovej, navyše uvádza zrejme nezachovanú klavírnu skladbu bez opusového čísla Epheu-Blatt, pri ktorej sa odvoláva na správu $\mathrm{z}$ viedenského periodika Deutsche Kunst- und Musikzeitung (roč. 1882, č. 38). Táto kompozícia môže rozšírit zoznam nezachovaných diel skladatel'ky uvádzaný Lengovou.

Vo výberovom zozname literatúry a prameňov na konci knihy čitatel' nájde aj zoznam novodobých vydaní diel Wurmbrand-Stuppachovej. Je sympatické, že jednu edíciu vy- dala autorka knihy (Pät' klavírnych skladieb op. 38). Ďalšiu sériu moderných vydaní skladatelkiných skladieb, vrátane cyklu Die schöne Melusine, vydalo v posledných rokoch vydavatel'stvo Certosa-Verlag, ktoré sa zameriava na tvorbu žien-skladateliek a vedie ho spomínaná Isolde Weiermüller-Backes. Lengová uvádza 5 notových edícií tohto vydavatel'stva, medzičasom $\mathrm{k}$ nim pribudla ešte jedna (Konzertetüde op. 44, Certosa Verlag W-S6). Editorom týchto vydaní je Dieter Michael Backes. Podobné snahy určite prispievajú $\mathrm{k}$ oživeniu recepcie diela Wurmbrand-Stuppachovej na medzinárodnej úrovni a nepriamo dosvedčujú jeho európske kvality. Skladatel'ku podla národnosti vnímajú v zahraničí ako „ungarisch“, svojou tvorbou však patrila do nemeckého kultúrneho kontextu. Sama skôr stelesňovala triezvy uhorský patriotizmus bratislavskej nobility a vnímala multietnický ráz svojho rodného mesta i metropoly monarchie, v ktorej prežila väčšiu čast’ svojho aktívneho života. Jana Lengová jej postoje $\mathrm{v}$ tejto oblasti interpretuje $s$ rozvahou a nadhladom, bez predpojatosti, čo môžeme len ocenit', rovnako ako fakt, že sa k nej ako bratislavskej rodáčke môžu hrdo hlásit aj Slováci. Prvým krokom v tomto smere je práve vydanie monografie od Jany Lengovej, ktorú možno všetkým záujemcom o klavírnu hudbu romantizmu a tiež dejiny hudby na Slovensku v 19. storočí vrelo odporučit'.

Peter Ruščin

\section{Lubomír Chalupka: Generačné a štýlové konfrontácie. Sprievodca slovenskou hudbou 20. storočia II. (1951 - 2000)}

Bratislava : Univerzita Komenského v Bratislave, 2018, 879 s. ISBN 978-80-223-4585-9

Monografia L'ubomíra Chalupku s názvom Generačné a štýlové konfrontácie. Sprievodca slovenskou hudbou 20. storočia II. (1951 - 2000) priamo nadväzuje na jeho predošlú prácu Cestami k tvorivej profesionalite, ktorá bola zameraná na vývoj slovenskej hudobnej kultúry počas prvých piatich decénií. $\mathrm{V}$ následnom pokračovaní autor podla vlastných slov organicky nadviazal na tie metodologické východiská a skúsenosti, ktoré ho viedli 